\title{
ANALISIS PENERAPAN KMK NOMOR 1981 TAHUN 2010 TENTANG PEDOMAN AKUNTANSI BADAN LAYANAN UMUM-RUMAH SAKIT PADA LAPORAN KEUANGAN BLUD RSUD CIMACAN
}

\section{ANALYSIS OF THE APPLICATION KMK NUMBER 1981 YEAR 2010 ABOUT ACCOUNTING GUIDELINES OF HOSPITAL PUBLIC SERVICE AGENCIES ON FINANCIAL STATEMENTS BLUD RSUD CIMACAN}

\author{
F Susandra1a dan M Yusuf ${ }^{1}$ \\ ${ }^{1}$ Program Studi Akuntansi, Fakultas Ekonomi, Universitas Djuanda Bogor, Jl. Tol Ciawi No. 1 \\ Kotak Pos 35 Ciawi Bogor 16720 \\ a Korespondensi: Farizka Susandra, Email: farizkasusandra@gmail.com \\ (Diterima: 11-12-2017; Ditelaah: 12-12-2017; Disetujui: 10-02-2018)
}

\begin{abstract}
This study aims to determine the application in presentation of financial statements RSUD Cimacan full PPK-BLUD status with reference to the decree of the Minister of health (KMK) number 1981/MENKES/SK/XII/2010 about accounting guidelines of hospital public service agencies approved by Minister of finance number S-5342/MK.5/2010. Data analysis is qualitative descriptive with comparative method that is compare the application and presentation of financial statements prepared by RSUD Cimacan with financial statement based on KMK Number 1981 Year 2010. Complete components for financial statements comprise the balance sheet, operational reports, cash flow and notes to financial statements. The results showed that the presentation of financial statements of RSUD Cimacan full BLUD status generally has been in accordance with KMK Number 1981 Year 2010 in representation of financial statements, but have yet to present a cash flow statement based Government Accounting Standarts (SAP) according PP Number 71 Year 2010 for reporting entity on financials in consolidation, as well as a need for interested parties.
\end{abstract}

Keywords : PPK-BLUD, KMK Number 1981 Year 2010, financial statements.

\begin{abstract}
ABSTRAK
Penelitian ini bertujuan untuk mengetahui penerapan dalam penyajian laporan keuangan RSUD Cimacan berstatus PPK-BLUD penuh dengan mengacu pada Keputusan Menteri Kesehatan (KMK) No.1981/2010 Tentang Pedoman Akuntansi Badan Layanan UmumRumah Sakit disetujui Menteri Keuangan dengan No. S-5342/MK.5/2010. Analisis data bersifat deskriptif kualitatif dengan metode komparatif yaitu membandingkan penerapan atas penyajian informasi laporan keuangan yang telah disusun RSUD Cimacan dengan laporan keuangan berdasarkan KMK No.1981 Tahun 2010. Komponen lengkap laporan keuangan terdiri dari neraca, laporan operasional, laporan arus kas \& CaLK. Hasil penelitian menunjukan bahwa penyajian pada laporan keuangan RSUD Cimacan berstatus BLUD penuh secara garis besar telah sesuai dengan KMK No. 1981/2010 dalam menyajikan laporan keuangan, namun belum menyajikan laporan arus kas berbasis Standar Akuntansi Pemerintah (SAP) yang disesuaikan didalam PP No.71/2010 untuk entitas pelaporan pada keuangannya dalam hal konsolidasi, juga sebagai kebutuhan untuk pihak berkepentingan.

Kata kunci: PPK-BLUD, KMK Nomor 1981 Tahun 2010, laporan keuangan.
\end{abstract}


Susandra, F., \& Yusuf, M. 2018. Analisis Penerapan KMK Nomor 1981 Tahun 2010 tentang Pedoman Akuntansi Badan Layanan Umum-Rumah Sakit pada Laporan Keuangan BLUD RSUD Cimacan. Jurnal Sosial Humaniora 9(1): 1-16.

\section{PENDAHULUAN}

Undang-Undang No. 1/2004 pasal ke-1 ayat 23 menyatakan bahwa Badan Layanan Umum adalah organisasi/instansi yang berposisi di lingkungan pemerintahan dibentuk dengan tujuan memberikan pelayanan terhadap masyarakat berupa tersedianya barang atau/dan jasa untuk dijual dengan tidak mencari keuntungan serta melakukan kegiatannya berdasarkan dari prinsip efisiensi dan produktifitas. PP No. 23/2005 pada pasal ke-1 ayat 1 kemudian mengadopsi BLU tentang pengelolaannya dengan tujuan dari BLU yakni meningkatkan pelayanan terhadap masyarakat sehingga dapat mencerdaskan masyarakat dan kesejahteraan untuk memajukan semua kalangan dalam memberikan fleksibilitas dan pengelolaan keuangan didasarkan atas penerapan kegiatan usaha yang berprinsip ekonomi dan sehat. Penetapan lembaga pemerintahan di RSU untuk menerapkan BLU untuk dapat meningkatkan akuntabilitas serta transparansi dalam bidang kesehatan.

Perkembangan status BLU menjadi acuan pemda (pemerintah daerah) dalam menjadikan RSUD sebagai BLUD. Permendagri No. 61/2007 membahas pedoman teknis dalam pengelolaan informasi keuangan BLUD menyatakan pada pasal ke-1 ayat 1 yang menjelaskan pengertian BLUD sebagai intansi pemerintah daerah terhadap diberikannya pelayanan untuk masyarakat baik berupa jasa atau barang yang tak mencari keuntungan berdasarkan produktifitas dan prinsip efisiensi. PPK-BLUD menerapkan kegiatan bisnis/usaha yang sehat sehingga dapat meningkatkan pelayanan kesehatan terhadap masyarakat untuk pengelolaan informasi keuangan daerah.
RSUD yang berubah status PPK-BLUD bukan merubah kepemilikan dan badan hukum. Badan hukum RSUD masih merupakan sebuah LTD dan kepemilikan tetap dalam pengelolaan pemerintah daerah, hanya saja pola pengelolaan keuangannya berubah menggunakan prinsip-prinsip BLUD.

UU No. 12/2011 pada pasal ke-7 ayat 1 menjelaskan peraturan perundangundangan sesuai jenis dan hierarkinya yang terdiri atas : 1). UUD 1945; 2). Ketetapan MPR; 3). UU; 4). Peraturan Presiden; 5). Perda Provinsi dan 6). Perda Kabupaten/Kota. Terbitnya Undang-Undang yang menempati posisi ke-3, maka secara pembenaran tidak beralasan untuk tidak menerapkan aturan dan ketentuan PPKBLUD. Undang-Undang No. 44/2009 merupakan hukum dalam bentuk UndangUndang hasil pembahasan DPR dan pemerintah.

Penegasan untuk menjalankan Pola Pengelolaan Keuangan-BLU rumah sakit terdapat didalam UU No. 44/2009 menjelaskan berkaitan dengan rumah sakit pada pasal ke-7 ayat 3 menyatakan rumah sakit pemda atau pemerintah pusat yang didirikan harus dalam bentuk unit pelaksana teknis pada instansi di bagian kesehatan, instansi tertentu, atau LTD dengan pengelolaan BLU ataupun BLUD dengan ketentuan-ketentuan dan peraturan atas perundang-undangan. Dipertegas lagi pada pasal ke-20 ayat 3 yang menyatakan rumah sakit publik yang dikelola oleh pemerintah baik pemerintah pusat ataupun daerah diselenggarakan atas dasar pengelolaan BLU ataupun BLUD sesuai peraturan dan ketentuan atas perundangundangan. Penerapan PPK-BLUD didalam unit kerja atau SKPD diharuskan memenuhi persyaratan teknis, substantif dan administratif. 
Adapun dalam penentuan status BLUD dalam Permendagri No. 61 Tahun 2007 dalam pengelolaan BLUD terhadap keuangannya terbagi menjadi :

1. BLUD penuh dimana meningkatnya status dari PPK-BLUD bertahap menjalankan PPK-BLUD penuh.

2. BLUD bertahap dimana menurunnya status dari PPK-BLUD penuh menjadi PPK-BLUD bertahap.

3. Kembalinya status unit kerja atau satuan kerja biasa dimana dicabutnya status baik dari status penuh maupun bertahap.

Rumah sakit berstatus BLU kedudukannya masih berada dalam lingkupan kementerian/lembaga RS yaitu Menteri Kesehatan. RSUD Cimacan menjalankan status BLUD penuh setelah ditetapkan tahun 2011, maka untuk laporan keuangan tersaji harus mengikuti BLU penuh dimana terdapat pada KMK No. 1981/2010 sebagai pedoman sekaligus aturan akuntansi untuk penyajian dan penerapan laporan keuangan bagian BLU penuh. Penetapan BLUD dilakukan perlima tahun, apabila semua persyaratan telah sesuai maka BLUD akan bertahan secara penuh, akan tetapi apabila persyaratan tidak terpenuhi bisa jadi kemungkinan statusnya akan menurun menjadi BLUD bertahap.

Laporan keuangan RSUD Cimacan secara organisasi belum diperiksa oleh auditor independen tetapi untuk hal konsolidasi dan pelaporan di Pemerintah Daerah Cianjur telah dilakukan audit oleh pihak BPK (Badan Pemeriksa Keuangan), dimana laporan konsolidasi dari entitas pelaporan di Kabupaten Cianjur digabungkan oleh Pemda Cianjur. RSUD Cimacan secara individual belum diaudit oleh pihak auditor terhadap informasi keuangan dikarenakan merasa cukup dengan BPK yang mengaudit pemda. RSUD Cimacan seharusnya mengajukan laporan keuangannya untuk diaudit. SPI (Satuan Pemeriksa Internal) juga terbatas dengan adanya tenaga profesional di RSUD kurang memadai dengan jumlah tenaga kerja oleh 8 orang bagian keuangan terdiri atas 3 orang PNS dan 5 orang non PNS dari jumlah 347 orang ketenagaan kerja dalam RSUD Cimacan.

Laporan keuangan RSUD berstatus BLU disusun untuk penyediaan informasi yang berkaitan pada kinerja atas keuangan, posisi keuangan \& perubahan terhadap keuangan. Penerapan akuntansi terhadap RSUD Cimacan sebagai BLUD penuh dari tahun 2011 sampai 2015 mengalami peningkatan dan perbaikan dalam penyusunan, penerapan dan penyajian terhadap laporan keuangan. Perkembangan laporan keuangan PPK-BLUD berbasis SAP dan SAK dapat dilihat sebagai ukuran dari pengembangan rumah sakit seperti pada tabel 1

Tabel 1 Perkembangan penyajian laporan keuangan RSUD Cimacan Tahun 2011-2015

\begin{tabular}{|c|c|c|}
\hline No & Tahun & $\begin{array}{c}\text { Penyajian Laporan Keuangan } \\
\text { sesuai BLU/BLUD }\end{array}$ \\
\hline 1 & 2011 & $\begin{array}{l}\text { Penetapan BLUD dengan } \\
\text { penilaian kinerja keuangan }\end{array}$ \\
\hline 2 & 2012 & $\begin{array}{l}\text { Penerapan akuntansi pada } \\
\text { BLUD berdasarkan SAP dan } \\
\text { masih menggunakan cash to } \\
\text { accrual }\end{array}$ \\
\hline 3 & 2013 & $\begin{array}{l}\text { Penerapan dan pengembangan } \\
\text { akuntansi berdasarkan SAP } \\
\text { dan masih menerapkan cash to } \\
\text { accrual basis }\end{array}$ \\
\hline 4 & 2014 & $\begin{array}{l}\text { Penerapan akuntansi } \\
\text { berdasarkan SAP, menerapkan } \\
\text { akuntansi berdasarkan SAK, } \\
\text { dan menerapkan accrual basis }\end{array}$ \\
\hline 5 & 2015 & $\begin{array}{l}\text { Penerapan akuntansi accrual } \\
\text { basis berdasarkan pada SAP } \\
\text { dan SAK dalam BLU/BLUD }\end{array}$ \\
\hline
\end{tabular}

Sumber: PPK-BLUD RSUD Cimacan, 2017.

Setiap lembaga pemerintahan mempunyai standar, aturan dan acuan dalam menjalankan kinerjanya seperti dari Rosnidah, dkk (2016) menjelaskan dalam mengidentifikasi eksisting sistem akuntansi BLUD pada RSUD Waled, Cirebon yang menerapkan aturan PPK-BLUD berdasarkan Permendagri No. 61 paragraf 116 tahun 2007 menjelaskan tentang BLUD harus menyajikan keuangan yang berbasis akrual 
bahwa RSUD Waled sudah menerapkan PPK-BLUD terhadap penyusunan laporan keuangannya tetapi belum merapkan basis akrual dan berpedoman pada SAK belum menggunakan SAP, maka RSUD Cimacan juga dibebankan menyusun keuangan sesuai PP No. 71/2010 sebagai SAP dan juga SAK ETAP dalam penyajiannya untuk dilaporkan ke pemda.

Penelitian terdahulu dari Widiastutik, dkk (2015) menganalisis penerapan PSAK No.45 \& PMK Nomor 76/2008 di unit usaha griya brawijaya di Universitas Brawijaya berstatus BLU dengan hasil penelitiannya menerangkan bahwa sebagian masih relevan dan sebagian masih perlu perbaikan untuk menerapkan keuangannya berdasarkan penyajian akuntansi BLU dikeuangannya atau sektor publik pemerintah serta Santi dan Rosita (2009) untuk mengetahui kendala PPK-BLU dengan hasil menunjukan kendala utama implementasi PK BLU yaitu perubahan mindset lama ke mindset baru dan permasalahan lainnya disebabkan hal administratif karena belum jelasnya atau belum adanya peraturan. Juga penelitian dari Eriotis, et al. (2009) menilai penerapan akuntansi accrual basis di RSU (Rumah Sakit Umum) Yunani dengan studi empiris. Hasil menunjukkan pada penerapan tingkat akuntansinya terhadap kualitas keuangan, perubahan sistem terkait pelatihan, tingkat pendidikan atas akuntansi serta konsultan professional berpengaruh positif. Namun, tidak adanya relasi signifikan terhadap ukuran rumah sakit, pelaksanaan perubahan biaya, background pendidikan, pengalaman, dan manajemen dokter. Sumbangan penelitian yaitu menyediakan pendekatan dan proses terhadap pemerintah Yunani untuk menerapkan akuntansi keuangan basis akrual dan akuntansi biaya dalam Greek National Health System (GNHS) dan peran tertentu dari faktor manusia, organisasi dan menempatkan situasional dalam implementasi tersebut.

Dalam penerapan dan pengembangan BLUD sesuai sistem akuntansinya diatur sebagaimana pada PP No. 23/2005 menjelaskan pengelolaan keuangan BLU, maka perlu diatur tentang ketentuan mengenai pedoman dan pelaporan pada keuangan BLUD dan menurut Permendagri No. 61/2007 pasal ke-116 ayat ke-1 menjelaskan bahwa BLUD menyelenggarakan akuntansi didalam laporan keuangan atas dasar SAK yang sudah diterbitkan asosiasi profesi akuntansi Indonesia pada kegiatan usaha/bisnis yang sehat. Berdasarkan pertimbangan inilah Menteri Kesehatan menetapkan KMK RI No. 1981/MENKES/SK/XII/2010 maka penyusunan, penyajian dan penerapan keuangan RSUD Cimacan yang telah berstatus BLUD, dimana RSUD merupakan objek Menteri Kesehatan harus menerapkan peraturan tersebut sebagai referensi untuk dikembangkannya akuntansi yang menyesuaikan dengan BLU-RS.

Berdasar uraian yang dijelaskan dan pentingnya nilai informasi keuangan BLUD, maka penelitian dilakukan dengan mengambil penerapan berkaitan terhadap akuntansi BLU-RS di RSUD Cimacan. Penelitian ini bertujuan untuk:

1. Untuk mengetahui serta menganalisis penyajian dan penerapan laporan keuangan RSUD Cimacan mengacu sesuai KMK No.1981/2010 untuk pedoman akuntansi BLU-RS.

2. Untuk mengetahui pelaporan keuangan RSUD Cimacan sesuai atau belum dengan BLU-RS.

Hasil penelitian nantinya diharapkan memberikan kebaikan dan bisa bermanfaat untuk melakukan pencocokan antara hubungan dari teori yang didapatkan dengan penerapan praktek akuntansi pada penyajian dan penerapannya di instansi yang berada didalam lingkungan pemerintah daerah. Penelitian yang dilakukan dapat memberi masukan dan saran untuk instansi pemerintah (khususnya RSUD Cimacan) sebagai bahan pertimbangan untuk pengambilan keputusan, mengetahui informasi keuangan dan pedoman dari peraturan yang 
disesuaikan terhadap rumah sakit sehingga dapat diterapkan serta untuk pemerintah dalam menetapkan aturan yang sesuai dan cocok pada akuntansi terhadap rumah sakit status BLU. Disamping itu, penelitian ini semoga dapat memberi informasi terkait peraturan yang disesuaikan oleh pemerintah untuk bisa diterapkan dalam penyusunan, penyajian dan penerapan laporan keuangan BLU/BLUD rumah sakit baik secara penuh ataupun bertahap.

\section{SAK (Standar Akuntansi Keuangan)}

SAK adalah Pernyataan SAK dan Interpretasi SAK yang sudah diterbitkan dari Dewan Standar IAI dan Dewan Standar Syariah IAI serta peraturan pasar modal sebagai regulator dalam entitas yang ada dibawah pengawasannya (sumber : http:iaiglobal.or.id). Ada empat diatur dalam SAK terhadap hal pokoknya, yaitu :
1. Pengakuan unsur-unsur laporan keuangan

2. Definisi elemen dan pos-pos informasi keuangan

3. Pengukuran unsur-unsur atas keuangan yang dilaporkan

4. Pengungkapan atau penyajian dari informasi finansial.

\section{SAP (Standar Akuntansi Pemerintah)}

PP No.71/2010 pasal ke-1 ayat 3 bahwa SAP adalah prinsip-prinsip untuk diterapkan didalam akuntansi terhadap penyusunan dan laporan keuangan pemerintahan yang disajikan. SAP yang digunakan sebelumnya adalah PP No.24/2005 yang menggunakan cash basis dan harus segera diganti dengan accrual basis yang dianggap lebih akuntabel dan lebih mencerminkan prinsip Good Government Govenrnance/Good Public Governance.

\section{Sistem Akuntansi BLU}

PMK No. 76/2008 pasal 5 menjelaskan sistem akuntansi adalah rangkaian prosedur baik terkomputerisasi ataupun manual mulai dari pencatatan, pengikhtisaran dan terkumpulnya data untuk diproses sampai operasi keuangan \& posisi keuangan yang dilaporkan. Sistem akuntansi dalam BLU yaitu sistem akuntansi biaya, sistem akuntansi keuangan dan sistem akuntansi aset tetap.

\section{Rumah Sakit Pemerintahan Berstatus BLU}

UU No. 44/2009 pasal ke-1 ayat 1 menjelaskan rumah sakit yaitu tempat atau institusi dengan menyelenggarakan pelayanannya terhadap kesehatan secara paripurna pada perorangan dengan penyediaan pelayanan UGD, rawat inap \& rawat jalan. Menurut BLU secara jenisnya terbagi kedalam tiga kelompok berikut:

1. BLU kegiatannya dengan menyediakan jasa atau barang

2. BLU yang mengelola wilayah ataupun kawasan

3. BLU dengan kegiatannya mengelola dana.

\section{Penyajian Laporan Keuangan}

Kieso dan Weygandt (2007:2) dengan bahasa yang dialihkan oleh Emil Salim menyatakan laporan keuangan yaitu sarana pengkomunikasian dari informasi keuangan terutama pada pihak-pihak dari luar korporasi dan Kasmir (2011;7) laporan menunjukan suatu kondisi atas keuangan instansi/perusahaan didalam periode dan jangka waktu tertentu atau saat ini. Penyajian secara wajar yaitu penyajian dari dampak yang terjadi untuk diperlihatkan secara jujur dari peristiwa, transaksi serta kondisi lain sesuai kriteria dan definisi dari pengakuan keuangan dari aset, liabilitas, pendapatan \& beban yang diatur didalam KDPPLK.

\section{Komponen Laporan Keuangan BLU- RS}

Komponen-komponennya meliputi beberapa aspek pada KMK Nomor 1981/Menkes/SK/XII/2010 yang menjelaskan ketentuan umum LK BLU-RS yang tersusun atas beberapa laporan pokok sebagai berikut : neraca, laporan aktivitas, 
laporan arus kas \& CaLK disertai dengan lampiran analisis rasio, laporan aktivitas disajikan komparatif dan lampiran lainnya sesuai kebutuhan. Selain itu juga mengatur aturan dan tata cara pada penyusunan, penerapan dan penggunaanya terhadap pihak yang berkaitan dan terlibat dengan penyusunan, penyajian, pelaporan dan pengungkapannya sebagai berikut : tanggung jawab laporan keuangan, bahasa laporan, mata uang pelaporan, kebijakan akuntansi, penyajian, konsistensi penyajian, materialitas dan agregasi, saling hapus, periode pelaporan, informasi komparatif dan interim.

\section{MATERI DAN METODE}

Objek penelitian adalah RSUD Cimacan bertempat di Jln.Cipanas No. 17 Cimacan Kec. Cipanas, Kab. Cianjur, Jawa Barat. Penelitian bersifat deskriptif dengan kualitatif yang memberikan gambaran latar belakang dari objek penelitian, sifat-sifat dan karakteristik dari yang diteliti. Penelitiannya menunjukan penelitian non hipotesis, sehingga dalam langkah penelitian tidak perlu membuat rumusan hipotesis. Jenis data yang dipergunakan berupa data subjek (Subject data) yaitu data berupa sikap, opini, pengalaman, karakteristik seseorang ataupun dari golongan yang menjadi subjek penelitian dan data dokumenter (Document data) yaitu laporan keuangan RSUD Cimacan tahun 2016.

Data-data penelitian yang dianalisis untuk diteliti, antara lain sebagai berikut.

1. Neraca

2. Laporan aktivitas/operasional

3. Laporan arus kas

4. CaLK (catatan atas laporan keuangan)

Adapun sumber data ada dua jenis yang digunakan yakni data primer berupa data subjek yang didapatkan dari sumber penelitian secara langsung yang memerlukan pengolahan lanjutan, bersumber serta diperoleh dari hasil wawancara/interview dengan pihak yang berhubungan oleh peneliti. Selanjutnya, data sekunder yakni data dari sumber instansi sebagai objek penelitian yang telah dikelola, diolah dan didokumentasikan.

\section{Analisis Data}

Penelitian menggunakan deskriptif pendekatan kualitatif dengan metode komparatif dengan dilakukannya sesuai cara dalam membandingkan penerapan akuntansi dalam kebijakan akuntansi terhadap penyusunan, penyajian dan penerapan laporan keuangan RSUD Cimacan berdasarkan KMK No. 1981/2010 BLU-RS. Metode komparatif digunakan untuk membandingkan perbedaan dan persamaan dari fakta-fakta, sifat-sifat dan karakteristik dari objek atas dasar kerangka pemikiran. Hal ini untuk membandingkan standar yang ada dari kegiatan praktek-praktek yang ditemui pada BLUD RSUD Cimacan.

Teknik dalam melakukan penelitian yang dipakai, yaitu :

1. Mengumpulkan data tentang penyajian dan penerapan laporan keuangan di instansi RSUD Cimacan yang diteliti dengan cara mengantarkan surat izin penelitian, mewawancara pihak BLUD RSUD Cimacan, menggali informasi tentang penggunaan standar akuntansi, mengetahui perkembangan penyajian dalam penerapan laporan keuangan sejak ditetapkan BLUD tahun 2011-2015 dan meminta data terkait penelitian.

2. Menganalisis data dengan cara membuat tabel yang berisi laporan keuangan tersaji pada RSUD Cimacan, membandingkan LK menurut KMK No. 1981/2010 dalam penyajiannya, sesuai atau tidak dengan alat analisis KMK Nomor 1981/2010 yang digunakan.

3. Membandingkan data yang didapat dengan teori atau alat analisis mengenai ketentuan laporan keuangan BLU-RS dengan membandingkan laporan keuangan RSUD Cimacan dalam pencatatan, pengakuan dan penyajian 
serta penerapan akuntansi sesuai KMK No. 1981 Tahun 2010.

4. Mendeskripsikan tabel laporan keuangan RSUD Cimacan, apakah telah sesuai atau belum meliputi neraca, laporan aktivitas/operasional, arus kas \& CaLK dengan KMK Nomor 1981/2010 sebagai pedoman akuntansi BLU-RS dalam penerapannya.

5. Menarik kesimpulan penelitian terhadap hasil atas disajikannya laporan keuangan telah sesuai atau belum dengan KMK Nomor 1981/2010 disertai penjelasan.

Analisis untuk melakukan perbandingan apakah format penyajian sesuai KMK No. 1981/2010 sebagai pedoman akuntansi pada status BLU di RSUD atau perlu penyesuaian kembali. Apabila laporan keuangan telah sesuai ketentuan-ketentuan yang terdapat didalam KMK No. 1981/2010 sebagai acuan akuntansi dalam BLU rumah sakit, maka penyajian tersebut adalah benar. Sebaliknya, apabila laporan keuangan tak sesuai atau belum dengan acuan KMK No. 1981/2010, maka penyajian akuntansi tersebut adalah salah dan perlu penyesuaian.

\section{HASIL DAN PEMBAHASAN}

CaLK RSUD Cimacan tahun 2016 menerangkan bahwa kebijakan akuntansi pemerintahan daerah adalah prinsipprinsip, dasar-dasar, konvensi-konvensi, aturan-aturan, dan praktik-pratik yang dipilih pemda sebagai pedoman dalam

Tabel 2 Perbandingan Neraca Tentang Penyajian Laporan Keuangan Menurut RSUD Cimacan dan Menurut KMK No. 1981/2010

\begin{tabular}{|c|c|c|c|c|}
\hline \multirow[b]{2}{*}{ No } & & \multirow{2}{*}{$\begin{array}{l}\text { Penyajian Laporan Keuangan } \\
\text { RSUD Cimacan }\end{array}$} & \multicolumn{2}{|c|}{ Hasil } \\
\hline & KMK & & Sesuai & $\begin{array}{l}\text { Tidak } \\
\text { Sesuai }\end{array}$ \\
\hline 1 & $\begin{array}{l}\text { Kas atau setara kas yaitu } \\
\text { akun/pos yang disajikan paling } \\
\text { lancar (likuid) dan lazim pada } \\
\text { urutan kesatu dalam unsur aset }\end{array}$ & $\begin{array}{l}\text { Kas atau setara kas disajikan pada } \\
\text { posisi pertama dalam neraca } \\
\text { dicatat dan diukur sesuai jumlah } \\
\text { nominal. Nilai nominal sesuai nilai } \\
\text { rupiahnya untuk disajikan, apabila } \\
\text { kas berbentuk valuta asing harus } \\
\text { dikonversi kedalam rupiah dengan }\end{array}$ & $\checkmark$ & \\
\hline
\end{tabular}

menyusun, menerapkan dan menyajikan laporan-laporan yan terkait dengan keuangan guna memenuhi kebutuhan stakeholders dalam meningkatkan keterbandingan terhadap anggaran, baik antar periode ataupun antar entitas. Basis akuntansi adalah basis akrual dimana pengeluaran \& penerimaan dicatat atau diakui ketika transaksi telah terjadi, bukan saat kas untuk transaksi diterima atau dibayarkan. Penyusunan, penyajian dan penerapan laporan keuangan RSUD Cimacan tahun 2016 mengacu pada SAP dari PP No. 71/2010 yang ditetapkan (Pergantian dari PP No. 24/2005) serta SAK ETAP untuk memenuhi kepentingan pihakpihak yang membutuhkan. RSUD Cimacan menggunakan SIMDA dalam aplikasinya dari pemda Cianjur dalam pencatatan dan penyusunan laporan keuangannya.

Perbandingan atau metode komparatif yang dilakukan untuk mengetahui sudah sesuaikah laporan keuangan dengan berstatus BLUD penuh di RSUD dengan aturan KMK No. 1981/2010 dengan status BLU rumah sakit, lebih jelasnya akan disajikan tabel perbandingan data-data yang diteliti serta hasil wawancara pada bagian keuangan RSUD Cimacan dapat dilihat di dalam tabel-tabel yang disajikan.

\section{Neraca}

Perbandingan Neraca Tentang Penyajian Laporan Keuangan Menurut RSUD Cimacan dan Menurut KMK No. 1981/2010 terdapat pada Tabel 2. 
kurs tengah yang digunakan berdasarkan BI pada tanggal dineracanya

2 Investasi lancar/jangka pendek Investasi jangka pendek pada bentuk deposito disajikan pada golongan dipos aset lancar sesuai nilai nominal, apabila investasi lancar dari setahun lebih maka akan tersajikan dalam neraca diinvestasi jangka panjang

3 Piutang disajikan pada golongan aset lancar sesuai jumlah neto dineraca, sedangkan piutang lain yang sudah jatuh tempo lebih dari satu tahun disajikan dalam golongan aset tak lancar serta piutang pelayanan dan piutang lain-lain disajikan dipos yang terpisah

golongan aset lancer disajikan sesuai nominal investasi yang bisa dicairkan dan kepemilikan selama kurang dari setahun atau 12 bulan serta disajikan di investasi jangka panjang melebihi satu tahun investasi dineraca

Piutang atau piutang lainnya disajikan pada pos digolongan aset lancar sejumlah dari nominal yang belum dibayar/dilunasi tetapi belum secara piutang bersih s/d tanggal pelaporan untuk setiap tagihan berdasar terbitan dari surat ketetapan kekurangan bayar atau semua utang tagihan oleh pengadilan pajak terhadap wajib pajak pada pegajuan banding yang ditetapkan atau setiap tagihan dalam proses yang masih banding terhadap keberatan dan belum ditetapkannya ganti rugi dari tuntutan majelis

4 Persediaan disajikan pada golongan aset lancar sebesar nilai perolehan

5 Beban dibayar dimuka pada aset lancar disajikan sesuai jumlah neto

6 Aset tetap sesuai nilai perolehan untuk disajikan dikurangi akumulasi penyusutan serta tanah disajikan sejumlah harga perolehan sesuai aset tetapnya

7 Aset tidak berwujud sebagai aset Persediaan disajikan pada golongan aset lancar sebesar harga akhir perolehan atau HPP akhir atau nilai yang wajar

Beban dibayar dimuka dipos aset lancar tersaji sesuai nominal bersih/neto

Aset tetap dan bagian aset tetap disajikan sesuai harga dari perolehan dengan akumulasi penyusutan yang dikurangi \& dinilai sesuai biaya perolehan. Apabila dinilai berdasar biaya perolehan yang tidak mungkinkan maka nilai aset tetap sesuai dasar nilai yang wajar saat perolehan aset tersebut

disajikan sesuai biaya perolehannya dengan dikurang akumulasi amortisasinya dan akumulasi penurunan nilainya

Aset tidak berwujud disajikan sejumlah biaya perolehannya adalah aset secara bentuk tidak berwujud atau tidak bisa dinyatakan secara fisiknya serta kepemilikannya untuk dapat 
8 Aset lainnya disajikan pada golongan pos aset lainnya secara terpisah

9 Kewajiban lancar pada neraca yang disajikan diantaranya: pendapatan diterima dimuka, beban masih harus dibayar, utang usaha, utang pajak, utang muka pasien dan utang lainnya dan apabila ada akun lain bisa dibentuk pos sendiri

10 Kewajiban jangka panjang tersaji sesuai biaya perolehan yang diamortisasi dan direklasifikasikan kedalam kewajiban di jangka pendek apabila telah jatuh tempo

11 Ekuitas dineraca disajikan sebesar saldo ekuitasnya dan dirinci berdasarkan jenis ekuitas menghasilkan jasa atau barang atau digunakan dengan tujuan lain termasuk Haki (Hak atas kekayaan intelektual)

Aset lainnya disajikan serta dicatat sebagai aset yang tak dapat dikelompokkan pada aset non berwujud misalnya tuntutan perbendaharaan, ganti rugi dan kemitraan dengan pihak ketiga Kewajiban lancar diklasifikasikan juga kewajiban pada jangka pendek jika sudah jatuh tempo 12 bulan serta disajikan sesuai akunakun yang dibentuk dalam pos-pos tersendiri yang terdapat di neraca

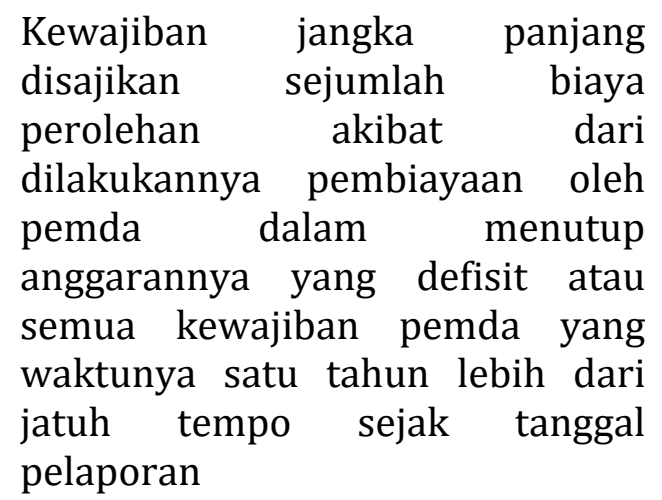

Ekuitas disajikan sesuai saldo ekuitas yang berupa hasil selisih dari aset \& kewajiban daerah
Berdasarkan tabel 2 menjelaskan tentang penyajian neraca laporan keuangan 2016 disusun RSUD Cimacan sesuai aturan standar KMK No. 1981/2010 hanya saja dalam penyajian piutang yang secara neto dengan akun penyisihan piutang dalam penyajian neracanya belum secara piutang bersih. KMK No. 1981/2010 menyebutkan bahwa piutang dineraca harus disajikan pada kelompok dipos aset lancar sebesar piutang bersih atau jumlah neto, sedangkan piutang-piutang lainnya setahun lebih sudah jatuh tempo disajikan pada golongan aset tidak lancar, piutang pelayanan \& piutang lainnya disajikan pada pos-pos yang terpisah. Dijelaskan pula, dalam CaLK RSUD Cimacan tahun 2016 saldo piutang lain-lain dari pendapatan sah untuk anggaran daerah merupakan piutang yang sampai $31 / 12 / 2016$ belum dilunasi sebesar $\mathrm{Rp}$ 2.597.702.400,- terdiri dari piutang pelayanan pasien BPJS dan pelayanan pasien Jamkesda/SKTM. Rekapitulasi piutang dan penyisihan piutang yang tak tertagih dapat dilihat dalam tabel 3 
Tabel 3 Rekapitulasi piutang lain-lain dan penyisihan piutang yang tidak tertagih

\begin{tabular}{lrlrr}
\hline Tahun & Jumlah Piutang & Umur Piutang & Prosentase & $\begin{array}{c}\text { Jumlah Penyisihan Piutang } \\
\text { yang Tidak Tertagih }\end{array}$ \\
\hline 2016 & $2.400 .690 .700,00$ & $>1$ bulan & $10 \%$ & $31.917 .809,50$ \\
& $197.011 .700,00$ & 1 bulan & $0,5 \%$ & $985.058,50$ \\
Jumlah & $2.597 .702 .400,00$ & & & $32.902 .868,00$ \\
\hline
\end{tabular}

Sumber : CaLK RSUD Cimacan, 2016.

Dari hasil perhitungan piutang tak tertagih, maka piutang sesuai nilai bersih terealisasi atau nilai dapat tertagih secara nominal dapat disajikan sehingga apabila berdasarkan CaLK RSUD Cimacan tahun 2016 maka piutang berdasarkan umur piutang, maka seharusnya disajikan sejumlah nilai bersih/neto untuk dimasukan kedalam neraca RSUD Cimacan tahun 2016 sebesar $\mathrm{Rp}$ 2.564.799.532,00 sedangkan yang disajikan neraca RSUD Cimacan tahun
2016 sebesar Rp 2.400.690.700,00 serta penyisihan piutang yang seharusnya $\mathrm{Rp}$ 32.902.868,00 disajikan $\mathrm{Rp} 31.917 .809,50$. Perbedaan antara neraca dengan CaLK mengenai penjelasan tentang pos neraca seharusnya disajikan sejumlah dengan piutang bersih untuk ditagih, padahal RSUD Cimacan sudah menjelaskan dalam CaLKnya mengenai piutang bersih. Rekapitulasi NRV (Net Realizable Value) untuk piutang lainlain dapat dilihat di Tabel 4.

Tabel 4 Rekapitulasi piutang bersih (NRV)

\begin{tabular}{lrrr}
\hline Uraian & Piutang Lain-lain & Penyisihan Piutang & Piutang Bersih (NRV) \\
\hline RSUD Cimacan & $2.597 .702 .400,00$ & $(32.902 .868,00)$ & $2.564 .799 .532,00$ \\
Jumlah & $2.597 .702 .400,00$ & $(32.902 .868,00)$ & $2.564 .799 .532,00$ \\
\hline
\end{tabular}

Sumber : CaLK RSUD Cimacan, 2016.

Berdasarkan penjelasan yang diuraikan, piutang pada neraca RSUD Cimacan 2016 dengan yang ditetapkan pada standar dari KMK No 1981/2010 masih sesuai, hanya saja yang dimasukan dalam piutang neracanya tidak sesuai nominal dengan piutang bersih (NRV) yang dijelaskan dalam CaLK RSUD Cimacan tahun 2016. Keseluruhan RSUD Cimacan sudah menerapkan neraca dengan pedoman dan aturan BLU.

\section{Laporan Operasional/Aktivitas}

Perbandingan laporan aktivitas atau operasional dalam penyajian laporan keuangan terdapat pada Tabel 5.

Tabel 5 Perbandingan laporan aktivitas/operasional dalam penyajian laporan keuangan menurut RSUD Cimacan dan KMK No. 1981/2010

\begin{tabular}{|c|c|c|c|c|}
\hline \multirow[b]{2}{*}{ No } & \multirow{2}{*}{$\begin{array}{l}\text { Penyajian Laporan keuangan } \\
\text { KMK }\end{array}$} & \multirow{2}{*}{$\begin{array}{c}\text { Penyajian Laporan Keuangan RSUD } \\
\text { Cimacan }\end{array}$} & \multicolumn{2}{|c|}{ Hasil } \\
\hline & & & Sesuai & $\begin{array}{l}\text { Tidak } \\
\text { Sesuai }\end{array}$ \\
\hline 1 & $\begin{array}{l}\text { Pendapatan secara } \\
\text { tersaji pada }\end{array}$ & $\begin{array}{l}\text { Pendapatan disajikan terpisah } \\
\text { dalam bagian pos-pos pendapatan }\end{array}$ & $\checkmark$ & \\
\hline 2 & $\begin{array}{l}\text { Beban disajikan } \quad \text { secara } \\
\text { kelompok tersendiri sebagai } \\
\text { pengurang dari pendapatan }\end{array}$ & $\begin{array}{l}\text { Beban-beban disajikan tersendiri } \\
\text { sesuai kelompok bagiannya dan } \\
\text { pengurang pendapatan }\end{array}$ & $\checkmark$ & \\
\hline 3 & $\begin{array}{l}\text { Laporan aktivitas/operasional } \\
\text { mencantumkan surplus/defisit } \\
\text { sebelum pos dan tahun } \\
\text { berjalan }\end{array}$ & $\begin{array}{l}\text { Laporan aktivitas atau operasional } \\
\text { RSUD Cimacan mencantumkan } \\
\text { surplus/defisit sebelum pos dan } \\
\text { tahun berjalan }\end{array}$ & $\checkmark$ & \\
\hline
\end{tabular}


Berdasarkan tabel 5 yang telah dianalisis secara keseluruhan RSUD Cimacan telah menyajikan laporan operasional atau laporan aktivitas sesuai dengan pedoman standar akuntansi pada BLU-RS. Jumlah saldo pendapatan asli daerah-LO pada RSUD Cimacan s/d 31/12/2016 sebesar Rp 19.477.435.808,-. Pendapatan secara terpisah untuk disajikan diantaranya pendapatan pajak daerah-LO, pendapatan

Tabel 6 Komposisi saldo beban dari hasil kekayaan yang dikelola dipisahkan-LO, pendapatan retribusi daerah-LO dan lain-lain. Pendapatan menjadi ukuran tercapainya kinerja instansi pemerintahan dalam bidang pengelolaan keuangannya, sedangkan saldo beban RSUD Cimacan Cianjur tahun 2016 sebesar Rp 39.029.689.834,-. Komposisi saldo beban RSUD Cimacan Cianjur tahun 2016 tersaji pada tabel 6 .

\begin{tabular}{llrr}
\hline \multirow{2}{*}{ No } & \multirow{2}{*}{ Uraian } & \multicolumn{2}{c}{ Jumlah } \\
\cline { 3 - 4 } & & \multicolumn{1}{c}{2016} & \multicolumn{1}{c}{2015} \\
\hline 1 & Beban Pegawai & $3.573 .063 .501,00$ & $4.082 .023 .302,00$ \\
2 & Beban Persediaan & 0,00 & 0,00 \\
3 & Beban Barang \& Jasa & $18.656 .836 .370,00$ & $9.118 .344 .072,00$ \\
4 & Beban Pemeliharaan & 0,00 & 0,00 \\
5 & Beban Perjalanan Dinas & 0,00 & 0,00 \\
6 & Beban Penyusutan dan Amortisasi & $16.757 .927 .115,00$ & $9.492 .791 .390,00$ \\
7 & Beban Penyisihan Piutang & $32.902 .868,00$ & $88.085 .226,64$ \\
8 & Beban Lain-lain & $8.959 .980,00$ & $51.988 .750,00$ \\
\multicolumn{2}{l}{ Jumlah } & $39.029 .689 .834,00$ & $23.253 .380 .966,64$ \\
\hline
\end{tabular}

Sumber : CaLK RSUD Cimacan, 2016.

RSUD Cimacan juga menyajikan saldo surplus/deficit pada laporan operasional dari kegiatan bukan operasional meskipun saldo yang dihasilkan sebesar Rp 0,- terdiri dari surplus penjualan dan defisit penjualan atas aset tak lancar. Surplus dan defisit laporan operasional merupakan akumulasi dari komponen-komponen laporan operasional dimana RSUD Cimacan tahun anggaran 2016 mengalami defisit sebesar Rp 19.552.254.026,- baik dari transaksi yang dianggarkan melalui anggaran belanja daerah dan pendapatan daerah maupun pendapatan BLUD yang diterima. Dari hasil analisis komparatif yang dilakukan bisa dinyatakan bahwa RSUD Cimacan telah menerapkan laporan operasionalnya sesuai dengan laporan operasional KMK No.1981/2010.

\section{Laporan Arus Kas}

Rumah Sakit Umum Daerah (RSUD) Cimacan tidak menyajikan informasi arus kas berdasarkan laporan organisasi pemerintah (SAP) dalam mengetahui kas keluar dan masuk dari kegiatannya, maka RSUD Cimacan belum sesuai menerapkan keuangan pada arus kas sesuai KMK No. 1981/2010 untuk pedoman rumah sakit pada penerapan akuntansinya tahun 2016 .

Penyesuaian laporan keuangan dari PP No. 71/2010 (Pergantian PP No. 24/2005) bahwa komponen-komponen keuangan untuk dijadikan laporan tersusun atas laporan finansial dan laporan anggaran (Budgeting reports) sehingga seluruh komponen yakni neraca, laporan anggaran yang terealisasi, laporan operasional/aktivitas, laporan perubahan SAL, arus kas, LPE dan CaLK. Komponenkomponen yang dijelaskan tersebut disajikan entitas pelaporan kecuali arus kas oleh entitas dengan fungsinya sebagai perbendaharaan umum untuk disajikan dan laporan SAL disajikan BUN dan yang menyusun konsolidasi keuangannya adalah entitas pelaporan (Firdaus, dkk. 2015) dan IAI menganjurkan dalam PSAK No. 2 pada ruang lingkup dan kegunaan informasi dari arus kas supaya setiap entitas harus 
menyusun arus kas disesuaikan dengan syarat-syarat yang ditetapkan dan bagian tidak terpisahkan untuk disajikan dalam setiap tahun periodenya serta memberikan informasi pengelolaan berupa penerimaan dan penggunaan kas, dinyatakan pula merupakan satu dari laporan pokok yang harus disusun untuk keputusan-keputusan ekonomi yang diambil (Wehantouw, 2015).

Laporan BLUD berupa arus kas akan dikonsolidasikan pada BUD (Bendahara Umum Daerah) seperti transaksi dari belanja, pendapatan, dan pembiayaan disahkan oleh BUD, sedangkan neraca, laporan anggaran yang terealisasi, laporan aktivitas, dan LPE dikonsolidasikan kepada pihak yang membawahi laporan entitas akuntansinya, juga dalam penerapannya RSUD Cimacan bukan merupakan fungsi perbendaharaan umum dalam pemerintah daerah kab.Cianjur, dimana dalam penyajian terhadap arus kas oleh pemda Cianjur sebagai BUD maka diperlukan informasi arus kas didalam laporan yang akan dikonsolidasikan.
RSUD Cimacan sudah membuat arus kas mengikuti SAK ETAP namun tidak membuat berdasarkan SAP sebagai kesesuaian dengan standar yang diikuti seharusnya RSUD Cimacan juga menyajikan berdasarkan SAP sebagai komponen lengkap dengan bentuk laporan sehingga para peneliti ataupun pihak lainnya untuk bisa lebih membandingkan memahami antara tahun sebelumnya dengan tahun sekarang serta untuk kepentingan konsolidasi.

\section{Catatan atas Laporan Keuangan}

KMK No. 1981 Tahun 2010 menjelaskan mengenai informasi dalam CaLK untuk disajikan, diantaranya sebagai berikut.
a. Pendahuluan
b. Kebijakan akuntansi
c. Penjelasan dari pos-pos neraca
d. Penjelasan dari pos-pos laporan operasional
e. Penjelasan dari pos-pos laporan arus kas
f. Kewajiban kontinjensi
g. Informasi tambahan serta pengungkapan lainnya.

Tabel 7 Perbandingan catatan atas laporan keuangan menurut RSUD Cimacan dan KMK No. $1981 / 2010$

\begin{tabular}{|c|c|c|c|c|}
\hline \multirow[b]{2}{*}{ No } & \multirow[b]{2}{*}{ Penyajian Laporan keuangan KMK } & \multirow{2}{*}{$\begin{array}{l}\text { Penyajian Laporan Keuangan } \\
\text { RSUD Cimacan }\end{array}$} & \multicolumn{2}{|l|}{ Hasil } \\
\hline & & & Sesuai & $\begin{array}{l}\text { Tidak } \\
\text { Sesuai }\end{array}$ \\
\hline 1 & $\begin{array}{l}\text { CaLK menyajikan gambaran umum } \\
\text { pada rumah sakitnya }\end{array}$ & $\begin{array}{l}\text { RSUD Cimacan menyajikan } \\
\text { gambaran umum }\end{array}$ & $\checkmark$ & \\
\hline 2 & $\begin{array}{l}\text { CaLK menyajikan ikhtisar } \\
\text { kebijakan akuntansi tertentu yang } \\
\text { isinya dasar dari penyusunan } \\
\text { keuangannya }\end{array}$ & $\begin{array}{l}\text { RSUD Cimacan menyajikan } \\
\text { kebijakan akuntansi \& dasar } \\
\text { laporan keuangan terhadap } \\
\text { penyusunannya }\end{array}$ & $\checkmark$ & \\
\hline 3 & $\begin{array}{l}\text { CaLK berisi penjelasan dari pos- } \\
\text { pos yang tersaji meliputi neraca, } \\
\text { laporan aktivitas, laporan arus kas } \\
\text { \& laporan lain yang berkaitan }\end{array}$ & $\begin{array}{l}\text { RSUD Cimacan menyajikan } \\
\text { CaLK berisi penjelasan sesuai } \\
\text { pos-pos keuangan dalam } \\
\text { laporannya }\end{array}$ & $\checkmark$ & \\
\hline
\end{tabular}

Dari tabel 7 bahwa CaLK RSUD Cimacan sesuai KMK No.1981/2010 sebagai acuan akuntansi BLU-RS. RSUD Cimacan membuat dan menyajikan CaLK yang berisi sebagai berikut: a. Pendahuluan berisi maksud, tujuan dan landasan hukum LK yang disusun.

b. Kebijakan akuntansi, ekonomi makro dan pencapaian kinerja APBD.

c. Ikhtisar dan hambatan pencapaian kinerja keuangan. 
d. Kebijakan akuntansi berisi entitas pelaporan, basis pengukuran dan dasar akuntansi keuangan yang akan diterapkan serta penerapan SAP.

e. Penjelasan dari pos-pos yang tersaji yaitu LRA, neraca, LO dan LPE.

f. Penjelasan informasi lain.

g. Penutup.

CaLK RSUD Cimacan sebagai BLUD penuh menyajikan informasi kuantitatif dan kualitatif sesuai aturan dari standar KMK No. 1981/2010. Penjelasan dari CaLK RSUD Cimacan tahun 2016 secara lengkap telah menjelaskan informasi yang terkait sehingga dapat dipertanggungjawabkan. Secara keseluruhan informasi dalam CaLK RSUD Cimacan tahun 2016 sudah menjelaskan secara rinci sesuai yang disajikan dan disusun, hanya saja belum terdapat analisis rasionya.

Analisis yang dilakukan pada LK RSUD Cimacan tahun 2016 dengan standar KMK No. 1981/MENKES/SK/XII/2010 merupakan pedoman akuntansi terhadap status BLU-RS menunjukan bahwa secara keseluruhan RSUD Cimacan telah menerapkan sesuai standar dalam akuntansi yang berstatus BLU untuk rumah sakit meliputi neraca, laporan operasional/laporan aktivitas, dan CaLK RSUD Cimacan periode 2016, hanya saja RSUD Cimacan tidak membuat arus kas mengikuti dasar SAP sesuai PP No.71/2010. Dari komponen lengkap dalam menyajikan keuangan yang dicatat, disajikan dan diungkapkan yang tersusun atas neraca, laporan operasional/aktivitas, laporan arus kas \& CaLK maka seharusnya RSUD Cimacan membuat arus kas sebagaimana aturan dan ketentuan yang berlaku.

KMK No. 1981 menyebutkan dalam tujuan laporan keuangan yang disajikan yaitu memberikan informasi berhubungan dengan keuangan sehingga memberi manfaat terhadap pengguna informasi secara rasional terhadap keputusan yang diambil, seperti : donatur (pemberi bantuan), investor, kreditor, otoritas pengawasan, pemerintah dan masyarakat.
Adapun manfaat bagi pengguna informasi keuangan, diantaranya :

1. Bagi pimpinan RSUD; pimpinan RSUD sangat membutuhkan informasi keuangan untuk memprediksi prospek pemberian layanan untuk masa selanjutnya sehingga pengambilan keputusan lebih berkualitas dan tepat sasaran di rumah sakit. Pimpinan RSUD dapat menilai sejauh mana RSUD dapat membiayai kegiatan pelayanan dan pembangunan pemerintahan dilihat atas dasar rasio kemandirian dilaporan keuangannya, untuk melihat tingkat kemandirian kinerja keuangan rumah sakit, mengefektifitaskan kinerja keuangan, dan mengefisienkan kinerja keuangan RSUD (Antari, 2014).

2. Bagi donatur (pemberi bantuan); menyediakan informasi dari keuangan yang berkaitan dalam memenuhi kepentingan dan kebutuhan pemberi bantuan, memberikan informasi keuangan dengan baik untuk para penyumbang agar tidak menghilangkan kepercayaan dan mengambil keputusan dalam menghentikan pendanaan terhadap organisasi bentuk nirlaba yang dikelolanya (Sulistiyoningsih, 2013).

3. Bagi investor; informasi sebagai bahan yang diikuti untuk dijadikan dalam mengambil keputusan. Pelaporan keuangan berdasarkan GCG untuk meningkatkan kepercayaan investor. Dengan kepercayaan dari pihak investor, maka penginvestasi akan menanamkan kembali investasinya terhadap instansi/perusahaan (Simadibrata, 2012).

4. Bagi kreditor; kreditor dapat mengetahui informasi kondisi keuangan, informasi kondisi ekonomi, informasi kepatuhan terhadap aturan, informasi kinerja, informasi rencana anggaran dan informasi naratif dalam keuangan (Yentifa, 2010).

5. Bagi otoritas pengawasan; otoritas pengawasan (seperti SPI, BPK dan auditor) bisa memberikan saran terhadap peningkatan mutu keuangan, 
harus lebih memperhatikan penerapan SPI dan SAP dengan mutu SDM yang benar-benar memiliki kompetensi keahlian dan integritas yang tinggi, sehingga paham terhadap standar atau aturan yang sudah ditetapkan (Susilawati dan Riana, 2014).

6. Bagi instansi pemerintah; informasi keuangan dijadikan kebenaran serta acuan dalam penetapan jumlah pajak. Instansi daerah tentunya selalu dalam pengawasan pemerintah baik daerah maupun pusat sehingga memberi kemudahan dalam pengendalian dan pengawasan keuangan. Dari suatu informasi keuangan instansi, pemerintah bisa menetapkan pajak yang mesti dibayar oleh organisasi bersangkutan sesuai yang ditetapkan (Irfani dan Dahria, 2009).

7. Bagi masyarakat; membantu orangorang terhadap penyediaan informasi yang berkecenderungan dan dapat mengetahui perkembangan keberlangsungan rumah sakit serta aktivitas pelayanannya serta memberikan informasi ruang pegawai yang dibutuhkan, memungkinkan untuk menerima sebuah lamaran pekerjaan dari publik dan penunjang kehidupan ekonomi masyarakat, mengukur informasi keuangan sudah sejauh mana dalam meningkatkan kemapuan instansi pemerintah dalam mencapai kinerja bagi kesejahteraan masyarakat, menjadi penilaian akuntabilitas di tingkat pemerintahan sehingga dapat lebih komprehensif serta mengukur indeks akuntabilitas lembaga pemerintah (Apriyanti, dkk. 2015).

Keuntungan status BLUD bagi RSUD dengan diterapkannya pedoman standar akuntansi BLU-RS yang dikeluarkan Menteri Kesehatan dalam KMK Nomor 1981/MENKES/SK/XII/2010, yaitu :

1. Pengelolaan keuangan terhadap RSUD menjadi lebih trasnparan dengan penyajian dan pelaporan menggunakan SAK dengan memberikan informasi dari keuangan pada neraca, laporan operasional/aktivitas, arus kas \& CaLK.

2. Memudahkan penyusunan untuk menyajikan keuangan sehingga memberikan informasi sesuai pedoman dan aturan dalam akuntansi RSUD yang berlaku.

3. Mengembangkan accrual basis dalam akuntansi yang disesuaikan dipelaporan keuangannya.

4. Penggunaan akuntansi memudahkan pemerintah untuk dapat mengawasi dan mengontrol keuangan pemerintahan.

5. Pendapatannya dapat digunakan oleh RSUD secara langsung meski tidak disetorkan hanya dilaporkan ke bagian keuangan dan departemen yang terkait.

6. Mengembangkan pelayanan dengan tersedianya dana kegiatan operasional rumah sakit.

7. Masih bisa mendapatkan subsidi pemerintahan diantaranya biaya operasional, modal dan biaya investasi.

8. Meningkatkan kualitas tenaga kerja sesuai dengan profesionalitasnya.

\section{KESIMPULAN DAN IMPLIKASI}

1. Penyajian laporan keuangan RSUD Cimacan berstatus BLUD penuh secara umum dan garis besar sesuai KMK No.1981/2010 sebagai pedoman akuntansi BLU-RS, tetapi belum secara penuh dalam menyajikan laporan keuangan BLUD dikarenakan RSUD Cimacan hanya menyajikan realisi anggaran, neraca, operasional, perubahan ekuitas \& calk namun belum menyajikan laporan arus kas basis SAP disesuaikan dalam PP No.71/ 2010 untuk entitas ke pemda Cianjur untuk entitas pelaporannya dalam konsolidasi keuangannya.

2. Pelaporan keuangan RSUD Cimacan berstatus BLUD penuh belum sesuai KMK BLU-RS dikarenakan belum menyajikan informasi arus kas yang merupakan komponen pelengkap 
laporan BLU rumah sakit, juga sebagai kebutuhan untuk pihak berkepentingan.

\section{DAFTAR PUSTAKA}

Antari, Gusti Ayu Yuni, 2016, Analisis Laporan Keuangan sebagai Dasar Menilai Kinerja Keuangan pada RSUD Bangli, Jurnal Jurusan Pendidikan Ekonomi (JJPE) Volume 7 No.2 tahun 2016, Universitas Pendidikan Ganesha, Singaraja.

Apriyanti, Dwi, Harpanto Guno Sabanu, dan Fahrizal Noor., 2015, Penilaian Indeks Akuntabilitas Instansi Pemerintah, Jurnal Tata Kelola dan Akuntabilitas Keuangan Negara Vol. 1 No.1, Juli 2015 : 21-42, BPK, Indonesia.

Arikunto, S, 2010, Prosedur Penelitian Suatu Pendekatan Praktek, Cetakan Ke-12, Edisi Revisi kelima, Rineka Cipta, Jakarta.

Belkaoui, Ahmed Riahi, 2006, Teori Akuntansi, Edisi Ke-5, Buku Ke-1, Salemba Empat, Jakarta.

Eriotis., Nikolaos, Fillipos Stamatiadis dan Dimitrios Vasiliou, 2009, Assessing Accrual Accounting Reform in Greek Public Hospitals; an Empirical Investigation, International Journal of Economic Sciences and Applied Research Volume 4 Issued 1:153-184, Munich Personal RePEc Archive (MPRA) Paper No. 30246, diposkan 24 April 2011 04:55 UT, University Of Athens, Greece.

Firdaus, Dahlia, Djoko Sigit Sayogo, dan Sri Wahjuni Latifah,2015, Evaluasi Penerapan PP No 71/201 Tentang SAP Basis Akrual; Studi Kasus di Pemda Nganjuk, Jurnal Akuntansi \& Investasi Volume 16 No.1, Januari 2015, Universitas Muhammadiyah, Malang.

Ikatan Akuntan Indonesia, 2009, Pernyataan Standar Akuntansi Keuangan, Jakarta.

Irfani, Halizah dan Muhamad Dahria, 2009,

Peran Akuntansi dalam Operasi Bisnis, Jurnal Saintikom volume 7 No.2, Agustus 2009, LPPM-STMIK Triguna Dharma, Medan.
Kasmir, 2011, Analisis Laporan Keuangan, Cetakan Keempat, PT.Raja Grafindo Persada, Jakarta.

Keputusan Menteri Kesehatan Nomor 1981 Tahun 2010, Tentang Pedoman Akuntansi Badan Layanan Umum-Rumah Sakit.

Kieso,D.E, Weygant, JJ, dan Warfield, T.D, 2007, Accounting Principle : Pengantar Akuntansi, Salemba Empat, Jakarta.

Mardiasmo, 2010, Akuntansi Sektor Publik, Andi, Yogyakarta.

Munawir, 2007, Analisa Laporan Keuangan, Cetakan Ke-14, Edisi Keempat, Liberty, Yogyakarta.

Peraturan Menteri Keuangan Nomor 76/PMK.05/2008, Tentang Pedoman Akuntansi dan Pelaporan Keuangan Badan Layanan Umum.

Peraturan Pemerintah Nomor 23 Tahun 2005, Tentang Pengelolaan Keuangan Badan Layanan Umum.

Peraturan Pemerintah Nomor 71 Tahun 2010, Tentang Standar Akuntansi Pemerintah.

Rosnidah, Ida, Juwenah, dan Apri Dwi Astuti, 2016, Identifikasi Eksiting Sistem Akuntansi BLUD pada RSUD Kabupaten Cirebon, Jurnal Riset \& Akuntansi Keuangan Volume 4 No. 2, pp ; 32-46. PISSN : 23381507.

Santi, Elsafitri, dan Irda Rosida, 2009, Implementasi dan Kendala Penerapan Pengelolaan Keuangan BLU, Jurnal Akuntansi dan Manajemen Volume 4 No.2, Desember 2009, ISSN: 1858-3687 hal. 41-54, Politeknik Negeri Padang.

Simadibrata, Theresia Adelia, 2012, Peranan Good Corporate Governance Terhadap Kualitas Pelaporan Keuangan dan Kepercayaan Investor, Jurnal Ilmiah Mahasiswa Akuntansi Vol. 1 No.4, Juli 2012, Unika Widya Mandala, Surabaya.

Sujarweni, V. Wiratna, 2014, Metodologi Penelitian, Pustaka Baru Press, Yogyakarta.

Sulistiyoningsih, Dewi, dan Ikhsan Budi Riharjo, 2013, Implementasi PSAK No.45 dalam Pelaporan Keuangan pada Yayasan Lembaga Pendidikan Zainuddin, Jurnal 
Ilmu \& Riset Akuntansi Vol. 2 No.1, STIESA Surabaya.

Surianto dan Laksono Trisnantoro, 2013, Evaluasi Penerapan Kebijakan dan Penerapan BLUD di RSUD Undata Provinsi Sulawesi Tengah, Jurnal Kebijakan Kesehatan Indonesia, Volume 2 No.1, Maret 2013, Universitas Gadjah Mada, Yogyakarta.

Susilawati dan Dwi Septiana Riana, 2014, SAP dan SPI sebagai Anteseden Kualitas Laporan Keuangan Pemerintah Daerah, Study and Accounting Research Volume XI No. 1, ISSN: 1693-4482, STIE STEMBI, Bandung.

Sutrisno, 2007, Manajemen Keuangan (Teori, Konsep dan Aplikasi), Edisi Kesatu, Cetakan Kelima, Ekonisia, Yogyakarta.

Undang-Undang Nomor 1 Tahun 2004, Tentang Perbendaharaan Negara.

Undang-Undang Nomor 44 Tahun 2009, Tentang Rumah Sakit.
Wehantouw, Andre B, dan Jantje J. Tinangon, 2015, Analisis Laporan Arus Kas Operasi, Investasi \& Pendanaan pada PT. Gudang Garam Tbk, Jurnal EMBA Volume 3 No.1, Maret 2015, hal 806-817, Universitas Sam Ratulangi, Manado.

Widiastutik, Niken, Susilawati, R. Anastasia Endang dan Abdul Halim, 2015, Analisis Penerapan PSAK No. 45 dan PMK No. 76/PMK.05/2008 Tentang Pelaporan Keuangan Organisasi Nirlaba pada Unit Bisnis Griya Brawijaya Universitas Brawijaya Berstatus BLU, Jurnal Riset Mahasiswa Akuntansi (JRMA), Universitas Kanjuruhan.

Yentifa, Armel, Yurniwati, dan Suhanda, 2010, Kebutuhan Investor \& Kreditor atas Informasi dalam Pelaporan Keuangan Pemerintah Daerah, Artikel Simposium Nasional Akuntansi XIII, Universitas Jenderal Soedirman, Purwokerto. 